\title{
Narsisistik Kişilik Örgütlenmesi ve Narsisistik \\ Savunmaların Nesne İlişkileri Kuramı Çerçevesinde İncelenmesi: Vaka ve Süpervizyon Çalışması
}

\author{
Çağdaş Yalçın ${ }^{1}$ \\ Beyza Ünal ${ }^{1}$ \\ Selva Ülbe ${ }^{2}$
}
${ }^{1}$ Orta Doğu Teknik Üniversitesi Psikoloji Bölümü ${ }^{2}$ Dokuz Eylül Üniversitesi Psikoloji Bölümü

\begin{abstract}
Özet
$\mathrm{Bu}$ çalışma narsisistik kişilik örüntüsüne sahip bir hastanın psikopatolojisinin hastanın kullandığı savunmaların ve hastanın nesne ilișkileri kuramı çerçevesinde incelenmesini, psikoterapi sürecini, karșı-aktarım ve karş1aktarımın psikoterapi sürecine etkisini ve süpervizyon sürecinin değerlendirilmesini içermektedir. Her bir bölümü aynı süpervizyon grubu içerisindeki farklı kişiler tarafindan yazılmış olan bu çalışma dört bölümden oluşmaktadır. Patolojik narsisizmi ve narsisistik savunmaları teorik açıdan inceleyen ilk bölüm terapistin süpervizyon grubundan akranı tarafından yazılmış ve bu incelemeler nesne ilişkileri kuramı çerçevesinde gerçekleştirilmiştir. Hastanın yaşam öyküsünün anlatıldığı ikinci bölüm ve psikoterapi sürecinin ele alındığı üçüncü bölüm hastanın terapisti tarafından yazılmış; hastanın semptomları nesne ilişkileri kuramı çerçevesinde incelenmiş ve hastanın terapistte yarattığ duygular ve bu duyguların psikoterapi süreci üzerindeki etkileri incelenmiştir. Süpervizyon sürecinin, süpervizör tarafından ele alındığı son bölümde ise hastadaki narsisistik kişilik örüntüsünün süpervizyon ortamına nasıl bir etkisinin olduğu, terapistin süreçleriyle birlikte nasıl değerlendirildiği ve bu değerlendirmenin terapi sürecine nasıl bir etkisinin olduğu aktarılmıştır.
\end{abstract}

Anahtar Kelimeler: Narsisistik Kişilik Örgütlenmesi, Narsisistik Savunmalar, Nesne İlişkileri Kuramı, Karşıaktarım Tepkileri, Süpervizyon

*İletişim: cagdasyalcinn@gmail.com

Gönderim Tarihi: 07.04.2017

Kabul Tarihi: 08.06.2017 


\title{
Narsisistik Kişilik Örgütlenmesi ve Narsisistik Savunmaların Nesne İliş̧kileri Kuramı Çerçevesinde İncelenmesi: Vaka ve Süpervizyon Çalışması
}

\author{
"Insan, istediği şeyi istediği anda yapıp, \\ yaptiklarl yanina kar kalan, eylemlerinin \\ sonuçlarından sorumlu olmayan, dünyanın \\ tümgüçlü efendisi değildir.” — Václav Havel
}

\section{Nesne İlişkileri Kuramı Açısından Narsisizm ve Narsisistik Savunmalar}

Narsisistik örüntüler herkesin içinde doğuştan var olmaktadır: her insan tabiatı gereği kendisi ve başardıkları hakkında iyi hissetmek isterken, aynı zamanda başkaları tarafından nasıl algılandığı konusunda hassastır ve aldığı tepkiler nedeniyle yaralanabilir. Değer verilen insanlardan takdir görmek özgüvenin artmasını sağlarken, onların kabulünü alamamak özgüveni sarsabilir. Bazı kişilerde öz-saygıyı güçlendiren bu narsisistik tedarikleri sağlamak diğer her şeyden daha önemli hale gelebilir ve kişi bu tedariklere ulaşmak yani onay almak ve eleştiri almamak için kendisiyle aşırı bir şekilde ilgilenebilir (McWilliams, 1994). Özetle, narsisizm dendiğinde kişilerin kendileriyle olan meşguliyetleri kastedilir ve diğer kişilik özellikleri gibi narsisizm de adaptif olandan adaptif olmayana doğru bir süremi içerisinde barındırır (Gabbard, 1994). Kişiler narsisistik tedarikleri elde etmeye gereğinden fazla yatırım yaptığında ve kim olduklarını kavrama konusunda büyük bir mücadele içerisine girdiklerinde, narsisistik örüntüler patolojik hale gelir. Psikodinamik yaklaşıma göre, bu durum kişilerin kendi içlerinde bulamadıkları ne varsa -güç, amaç, kabul ve önemli olma hissi- başkalarından edinme ihtimalini artıracak yollara başvurmalarına neden olabilir (Luchner, Mirsalimi, Moser, \& Jones, 2008).

Narsisizmde kendilik algısına bakıldığında, Kernberg (1975) narsisistik patolojiye sahip kişilerde, kişilerin ideal kendiliği, gerçek kendiliği ve ideal nesnesinin patolojik bir birleşiminden söz etmektedir. Klinik olarak, böyle kişilerin, başkalarından ihtiyaç duyduğu ve kendisi için istediği her şey yine kendisinin içindedir. Bu nedenle, narsisistik örüntülerde kişi başka bir kimseye ihtiyaç duymadığı ve tamamen kendine yeter bir durumda olduğu algısı içindedir. Kernberg (1975)'e göre kişinin öz-yeterliliğe duyduğu bu ihtiyaç patolojik nesne ilişkilerinin temel bir parçasıdır; bu öz-yeterlilik hissi ile narsisistik kişiler bir diğer kişinin (ideal nesne) ayrı varlığını ve bu diğer kişi için besledikleri çaresizlik, haset ve öfke duygularını kabul etmek zorunda kalmazlar. Kernberg (1975)'in formülünün merkezinde, narsisistik bireyin diğer kişiye karşı hissettiği haset ve öfke duygularını tolere edememesi vardır. Narsisistik kişinin patolojik iç dünyası, kendisinden ayrı olmasını kontrol edemediği ideal nesneyle olan ilişkisinde ona olan ihtiyacını, hasetini ve öfkesini inkâr eder. Öfke ve değersizleştirme yoluyla narsisistik hastalar diğer kişiye olan yoğun ihtiyacını reddetse de boşluk hissi, can sıkıntısı, huzursuzluk, geçici olarak toplumdan geri çekilme, empatiden yoksunluk, dışarıdan hayranlık duyulma ihtiyacı, ilişkilerden yüzeysel tatmin sağlama gibi büyük bedeller ödemek zorunda kalabilirler.

Patolojik narsisistik örüntüler geliştirme riskinde olan kişilerin duygulanımlarında oldukça hassas oldukları görülmektedir. Klinik literatürde, özellikle utanç ve haset duyguları narsisistik örüntü ile ilişsilendirilmiştir. Narsisistik kişilik örüntüsüne sahip kişiler belirli yönlerden kendiliklerinin eksiklikleri olduğunu düşündükleri için utanç duygusu hissedebilirler; utandırılma korkusu buna eşlik edebilir. Bu kişiler, kendilikleri ile ilgili tutarlılıklarının zayıf olduğunu içten içe hissettikleri için, özsaygılarını kaybetmekten, dağılmaktan ve "hiç kimse" olmaktan oldukça korkarlar. Ayrıca, narsisistik kişiler kusurlarının olmadığı ve başka kişilere ihtiyaç duymadığı yanılgıları üzerine bir kendilik inşa etmeye çalıştıkları için, hata yapabilirliklerinin ve başka kişilere bağımlı olma duygularının ortaya çıkmasını çok utanç verici bulurlar, bu yüzden özür ve teşekkür ifadeleri samimiyetten uzaktır. Bununla beraber, kendilerinde olmasını diledikleri niteliklere sahip kişileri ya da kendileriyle mutlu olan insanları 
gördüklerinde haset duygusuna kapılabilirler. Haset duygusuyla baş edebilmek için bu kişilere karş1 yargılayıcı ve küçümseyici bir tutum sergileyebilirler (McWilliams, 1994).

Narsisistik örüntüler kendini farklı şekillerde gösterebilir. Bu kişiler kendilerini anlık olarak iyi hissetmek için sürekli ben merkezli olma ve başkaları tarafından sürekli övgü ve fark edilme eğilimi içindedirler. Sürekli bir kendilik değerine sahip olmak yerine, başkaları tarafından tekrar tekrar desteklenmeye ihtiyaç duyarlar. Başkalarıyla olan ilişkilerinde diğer insanların duygularına ve ihtiyaçlarına karşı sömürücü ve duygusuz olma eğilimindedirler. Davranışları bir taraftan büyüleyici ve çekici olsa da, diğer taraftan ilgisiz ve kibirli olabilir. Karşılığında hiçbir şey vermeksizin, etrafındaki insanlardan kendilerine özel ayrıcalıklar bekleyebilirler, ancak eleştirildiklerini düşündüklerinde ya da insanlar kendilerine istedikleri şekilde davranmadığında kolayca aşağılanmış ya da utanmış hissedebilirler ve yoğun bir öfkeyle cevap verebilirler. Bazıları insanların kendi zayıflıklarını görmelerine izin vermekle soğuk bir mesafe koymak arasında gidip gelebilir, diğerleri ise kibirli görünüşleri devamlı bir şekilde sürdürürler. Çoğu iç dünyasını "boş" olarak tanımlar ve "sahte" olduğunu hisseder. Çoğunun mükemmel başarı, aşk, zenginlik ve güçle ilgili detaylı fantezileri vardır(McWilliams, 1994).

Narsisistik kişilik özelliklerine sahip kişilerin kullandığı savunmalara gelindiğinde, mükemmeliyetçiliğin bu örüntüdeki kişilerin sıklıkla başvurduğu savunmalardan biri olduğu görülmektedir. Narsisistik kişiler kendilerini gerçeküstü standartlara göre değerlendirirler. Bunun sonucunda ya kendilerini bu standartlara ulaştıklarına inandırırlar (büyüklenmeci) ya da kendilerini her insan gibi kusurları olan biri olarak görmek yerine doğuştan kusurlu biri olarak görürler (depresif). Ayrıca bu kişiler mükemmeliyetçiliklerinden dolayı kendiliklerini ya da diğer kişileri sürekli eleştirme eğilimi içindedirler ve terapiye başvurma nedenleri de genellikle kendiliklerini mükemmelleştirmektir (McWilliams, 2010).

İdealizasyon ve değersizleştirme ise narsistik güdülenme eğiliminde olan kişilerin en göze çarpan savunma biçimlerindendir. Narsisistik kişiler genelde kendilerini idealize ettiğinde diğer kişileri değersizleştirir; diğerlerini idealleştirdiğinde kendiliğini değersizleştirir. Bu savunma biçimleri terapi sırasında da kendini gösterir. Ancak verdikleri bu tepkilerin terapistte nasıl duygular uyandıracağı konusunda duyarsızdırlar. Değersizleştirdikleri terapistin kendilerinin eleştirel tutumları üzerine konuşmasını savunucu bir tutum olarak yorumlarken, idealize ettikleri terapistin hastanın kendisine verdiği aşırı değeri terapide ele almasının terapistin tevazuundan ileri geldiğini düşünebilirler. Ancak terapiye yeni başlayan terapistlerin genellikle değersizleştirme ile karşılaştıkları görülmektedir (McWilliams, 1994). Kernberg (1975) değersizleştirmenin, hastanın haset duygusunu kontrol altında tutma çabasından geldiğini iddia etmiştir. Yansıtmalı özdeşim aracılığıyla hasta değersizleştirilmiş kendiliğini terapiste yerleştirir ve değersizleştirme karşı aktarıma neden olur (Adler, 1986). Değersizleştirme sonucunda, terapist görmezden gelinmiş olma gibi karşı aktarım duygularına sahip olabilir. Hastanın kendisini öz değerini yükseltmek için bir araç olarak kullanmasını can sıkıcı bulabilir ve kendisini kusurlu hissedebilir (McWilliams, 2010). Bunun yanında sıkılma, öfkelenme, uyuklama ve tedavide ilerleme yokmuş hissini deneyimleyebilirler. Süpervizyon sırasında terapistin seanslara dair tepkisi şu şekilde olabilir:

"Her hafta geliyor, her hafta içinde yaşadığı olayları bunlar hakkında neler düşündüğüyle anlatıyor, kıyafetlerimi eleştiriyor, yaptığım tüm terapatik müdahaleleri baştan savıyor ve seans süresi bitince gidiyor. Peki niye her hafta tekrar tekrar geliyor buraya? Böyle devam eden görüşmelerden ne elde ediyor?" (McWilliams, 2010, s. 219).

Savunucu tutumlar, terapisti değersizleştirme ile birleştiğinde, sözel agresyon narsisistik örüntünün çekirdeğini oluşturur. Kernberg (1975)'e göre narsisistik kişilik örüntüsüne sahip kişiler öfke ve haset duygularının terapisti ile ilişsisini ve yardım alma umudunu yok edeceği korkusunu da yaşarlar (akt. Adler, 1986). Öfkenin ve saldırganlığın terapist ile ilişkiye zarar vereceği düşüncesi Klein (1965)'ın nesne ilişkileri kuramı ışığında daha net bir şekilde açıklanabilir. Klein (1957)'a göre, haset duygusu kişinin 
kendisinin dışında bir iyiye katlanamamasıyla ortaya çıkmakta ve kendiliğin saldırgan parçaları iyi nesneye yansitılmaktadır. Bu şekilde, iyi nesne üzerinde kontrol kurabilme amaçlanır (akt. Tura, 2005). Ancak, bu yansıtma, kişinin karşılık olarak zulmedileceği veya iyi nesneye zarar vererek onu yok edeceği kaygısını yaşamasına neden olur (Klein, 1935/2012). Özetle, terapistine öfke ve haset duyguları besleyen hastalar da, yukarıda anlatılan sürecin sonunda terapistinden zarar göreceği ya da terapistine zarar vereceği kaygısını da taşıyabilirler. Dolayısıyla, bu duyguların yoğun olarak yaşandığı durumlarda, iyi nesneden faydalanmaları da gittikçe zorlaşabilir.

Şimdiye kadar olan bölümde narsisizm kuramsal olarak ele alınmıştır. Bundan sonrasında Ayna Klinik Psikoloji Ünitesi’nde yürütülmüş ve narsisistik kişilik örüntüsü sergilediği düşünülen bir hastanın psikoterapi süreci, bu örüntüyü ortaya çıkaran ve besleyen yaşam öyküsü, başvuruya neden olan ilişkisel sorunları ve bütün bunlara bağlı olarak, terapi ilişkisinde yeniden canlandırdığı duygular, kuramsal çerçevede ele alınacaktır. Vaka sunumunda, kimliğgi ortaya çıkarabilecek kişisel bilgiler gizliliğin sağlanması amacıyla değiştirilmiştir.

\section{Vakanın Tanıtılması}

Ayna Klinik Psikoloji Ünitesi aracılığı ile randevu alan Özge Hanım'ın ilk görüşmesi sınav, hastalık, telefonuna ulaşılamaması gibi sebeplerle dört hafta rötarlı olarak gerçekleştirilmiştir. Özge Hanım'ın, psikoterapi süreci içerisinde de sık sık fizyolojik rahatsızlıklarını ya da Ankara'da gerçekleşen patlamaları neden göstererek seanslara gelmediği olmuştur. Toplamda Özge Hanım ile aralıklı olarak 12 seans yapılmıştır.

Özge Hanım 23 yaşında üniversite öğrencisidir. Kimya bölümünde okumakta olan Özge Hanım üniversitedeki 4. senesindedir ancak hala 1. sınıf derslerini almaktadır. Babası ve annesi emekli memur olan Özge Hanım'ın, kendinden 11 yaş büyük bir abisi bulunmaktadır ve abisi de Ankara'da yaşamakta ve mühendis olarak özel bir şirkette çalışmaktadır. Özge Hanım, annesini ilgisiz ve soğuk bir kadın olarak tarif etmiştir. Özge Hanım, annesine oldukça kızgındır ve annesinin, hayatında gerçekleşen hiçbir şeyin farkında olmadığını ifade etmiştir. Babasının ise kendini devrimci olarak nitelendiren ancak gerçekte öyle davranmayan "saçma sapan" biri olduğunu belirten Özge Hanım, babasının evde bütün sorunların Özge Hanım'dan kaynaklandığını düşündüğünü, sürekli kendini acındıracak davranışlar sergilediğini ve sağlık problemlerini bahane ederek Özge Hanım'ın evden kopmasının önünü tıkadığını ifade etmiştir. Özge Hanım babasıyla ilişkisinin geçmiş dönemde daha iyi olduğunu ancak babasının sık ve nedensiz yere on dakikaya geleceğim dedikten bir saat sonra bile gelmemesi gibi yalanlar söylemesi nedeniyle onu hayal kırıklığına uğrattığını ve ilişkilerinin artık iyi olmadığını ifade etmiştir. Özge Hanım abisini ailede sorunları çözen ve rasyonel biri olarak tanımlamış ve abisinin evlenmesi nedeniyle terk edilmiş hissettiğini ifade etmiştir. Anne ve babasının takdirini hiç alamadığını ifade eden Özge Hanım, takdir edilenin hep abisi olduğunu ve ailesinin abisinin isteklerine göre hayatlarını düzenlerken, Özge Hanım'ı görmezden geldiklerini ifade etmiştir.

Geçmişinde, deprem, babasının geçirdiği bir trafik kazası gibi sebeplerle sık okul değiştirmek zorunda kalan Özge Hanım, okul hayatında yakın arkadaşlıklar kuramadığını, okulun popüler kızlarından biri olamadığını, fiziksel anlamda erken gelişmesi nedeniyle en arka sıraya atılan biri olduğunu ve bu dönemde okuldaki akranlarına tebeşir tozlarını birleştirip tekrar tebeşir yapabildiği, kırtasiyeden kalemi ücretsiz aldığı benzeri yalanları sık sık söyleyip onları kandırdığını ifade etmiştir.

Özge Hanım psikoterapiye majör depresif bozukluk tanısı ile geldiğini ve bu tanıyı lisede aldığını ifade etmiştir. Lise yıllarından bu yana ilaç kullanan Özge Hanım buna ek olarak bugüne kadar iki farklı terapistten psikoterapi almıştır, ancak bu iki terapiyi de sonlandırmadan bırakmıştır. İlk psikoterapi tecrübesine yaklaşık 6 ay devam eden Özge Hanım, ikinci kez psikoterapiye başladığında 3 seans devam etmiştir. Depresif duygu durumunun lisede hayatının anlamını sorgulamasıyla başladığını ifade eden Özge 
Hanım, sonraki süreçte hayatına anlam katma girişimlerinin olduğunu (politik partilere katılmak vb.) ancak bu girişimlerinde hayal kırıklığına uğradığını ve sonrasında depresyona girdiğini ifade etmiştir. Geçmişinde iki intihar girişimi olan Özge Hanım'ın ilk girişimi lise başında politik bir yapılanmaya gitmeye başlaması sebebiyle babasının onu eve kapatması sonucunda gerçekleşmiştir. Evdeki ilaçları içen Özge Hanım'ın girişimi sonrasında midesi yıkanmıştır. Bu intihar girişiminden sonra babasının "sen nasıl devrimcisin" dediğini hatırlayan Özge Hanım babasının bu sözlerine hala oldukça öfkelidir. Diğer intihar girişimi ise abisinin evlenmesi sonrasında gerçekleşmiştir ve yine lise dönemindedir. Abisinin evlenerek onu terk ettiğini düşünen Özge Hanım abisinin bu girişimden sonra evlenmekten vazgeçeceğini düşünmüştür. Bu intihar denemelerinin ailesi üzerinde Özge Hanım'ın isteklerini kabul etme, evlilikten vazgeçme gibi değiştirici etkilerinin olmasını beklediğini ifade eden Özge Hanım, ailesinin ne gibi yanlışlar yaparak kendisini intihara sürüklediğini hiç düşünmediklerini ifade etmiştir. Terapiye başladığı dönemde ve psikoterapi sürecinde Özge Hanım'ın herhangi bir intihar isteği ve düşüncesi bulunmamaktadır. Diğer bir taraftan Özge Hanım'ın terapi başlangıcında ailesi ve arkadaşlarıyla yoğun ilişkisel ve öfke kontrol problemleri bulunmaktadır. Özge Hanım, görüşmeler boyunca aile üyelerinin ve arkadaşlarının ona hak ettiklerini vermediklerini sıklıkla ifade etmiştir. Özge Hanım’a göre abisine, abisinin eşine, abisinin çocuğuna ya da ona göre daha az “entelektüel birikime sahip" arkadaşlarına kendine gösterilen ilgiye nazaran daha çok ilgi gösterildiğini seanslarda sık sık ifade etmiştir:

"ben tok evin aç kedisiyim... yeğenim geldiğinde bu dolabı dolduruyorsunuz, ben okulda yiyecek ekmek parası bulamıyorum... arkadaşlarımın aileleri kirada oturup, üzerlerinde borç olup yine de çocuklarının en lüksünden en temel ihtiyaçlarını karşılıyorlar"

Yukarıda terapiye geliş nedeni, yaşam öyküsü ve terapi süresince ilişkilerine dair ifadelerine değinilen Özge Hanım'ın kişilik örgütlenmesi, kullandığı savunmalar ve psikoterapistte yarattığı duygular, makalenin devamında nesne ilişkileri kuramı literatürü çerçevesinde incelenmiş ve bu literatüre uygun şekilde örneklendirilmiştir.

\section{Vakanın Literatür Işı̆̆ında İncelenmesi}

Özge Hanım'ın ailesi ve arkadaşlarıyla ilişkisine dair anlatısı psikoterapi süreci boyunca Melanie Klein'ın (1957) haset kavramı ile ilişkili olarak ele alınmıştır. Klein'e göre haset, erken dönemde kişinin iyi nesneyi kurma yolunda karşılaştığı zorlukları arttırır; çünkü bebek, yoksun kaldığı doyumun onu hüsrana uğratan meme tarafından alıkonduğuna inanıyordur. Yukarıda verilen tanıma paralel şekilde Özge Hanım'ın ilişkilerinde ifade ettiği problemler, ihtiyaçlarının giderilmemesi çerçevesinde şekillenmektedir. Yukarıda belirtildiği üzere annesini soğuk ve ilgisiz, anne ve babasını onun ihtiyaçlarını göz ardı eden ve abisini terk edip giden biri olarak nitelendiren Özge Hanım, seanslar süresince hem ailesiyle hem de arkadaşlarıyla benzer problemleri yaşamayı sürdürmüştür. Bu, ihtiyaçlarının giderilmemesi hali psikoterapiye de yansımış ve Özge Hanım henüz ilk görüşmede terapistinin bu kadar genç olmasını beklemediğini ifade etmiştir. Terapistinin onun sorunları ile baş edip edemeyeceği konusunda kuşkulandığını ileten Özge Hanım'ın ilerleyen seanslarda ise terapistin onu yeterince önemsemediğine, yaptığı yorumların sığ olduğuna ve başından savmaya çalıştığına dair ifadeleri olmuştur.

Hastanın yapılan yorumları seans sırasında değersizleştirmesine ek olarak ilerleyen seanslarda hastanın seans sırasında ona iyi gelen yorumu bir sonraki seansta değersizleştirdiği ya da saldırgan bir yorum olarak algıladığı gözlemlenmiştir. Benzer bir şekilde Özge Hanım hayatındaki diğer insanlarla ilgili yorum ve davranışlarında da değersizleştirmeyi sık sık kullanmakta ve ihtiyaçlarını karşılayan ilişkiler kuramamaktadır. Özge Hanım etrafındaki insanları genellikle "sı̆̆" olarak nitelendirmekte ve onun gibi entelektüel uğraşları olmaması sebebiyle onlardan farklı bir tutumu hak ettiğini ifade etmektedir. 
Yukarıda örneklendirilen savunmalarına ek olarak terapiye hipokondriyal problemler ve ölüm ile ilgili kaygılar sebebiyle sık sık gelmeyen Özge Hanım'ın hipokondriyal ve ölüm ile ilgili uğraşlarının, narsisistik hastalarda gözlemlenen içsel kendiliklerinin parçalanma korkusu ve kişiliklerinin bazı gerginlikler ile başa çıkmada çok zayıf olduklarını hissetmelerinin bir sonucu olduğu düşünülmüştür (McWilliams, 2010).

Özge Hanım'ın seanslar süresince ailesiyle, arkadaşlarıyla ve terapistiyle ilişkisinde kullandığı değersizleştirme terapötik ittifakın kurulması açısından da çeşitli sıkıntılara yol açmıştır. Değersizleştirme sonrası terapist çoğunlukla öfke hissetmiş ve seans sırasında hissettiği öfke spontanlığının ve seanslarda hasta ile empati kurmasının önünde bir engel teşkil etmiştir. Terapistin seans sırasında hissettiği öfke karşıaktarım olarak değerlendirilmiştir. Farklı dönemlerde farklı şekillerde kavramsallaştırılan karşı-aktarım, Sigmund Freud'a göre aşılması gereken bir engeldir. Psikoterapist bilinçdışında hastayı geçmişinden biri gibi tecrübe eder ve bu çerçevede karşı aktarım psikoterapistin hastaya aktarımı olarak kavramsallaştırılabilir (Freud, 1910/1957, akt. Gabbard, 1999). Paula Heimann (1950, akt. Gabbard, 1999) ise karş1 aktarımı daha geniş bir çerçevede değerlendirmiş ve psikoterapistin duygusal reaksiyonunun sadece terapistin geçmişinden kaynaklanan bir engel değil, hastanın bilinçdışını anlamada önemli bir araç olduğunu öne sürmüştür. Ancak Heimann karşı aktarımı yararlı bir bilgi olarak görmesine rağmen terapistin kendi duygularını hastaya açmasına karşı çıkmıştır. Güncel görüş ise karşı aktarımın hastayla ilgili yararlı bir bilgi kaynağı olabileceği fikrini kabul etmektedir. Buna ek olarak psikoterapistin kendi öznelliğinin de hastanın davranışlarının nasıl algılandığı üzerinde bir etkisi olduğu düşünülmektedir. Dolayısıyla hasta terapisti hastanın iç dünyasını yansıtan bir rol oynamaya çeker ancak bu rolün spesifik boyutları terapistin kendi kişiliği tarafından renklendirilir (Gabbard, 1999). Buna ek olarak terapistin hissettiği duyguları anlamlandırırken, hastanın kişilik örgütlenmesinin rolünü de göz ardı etmemek gerekmektedir. Nancy McWilliams (2010) narsisistik kişilerin ebeveynlerii gibi ayrı bir iç nesneyi terapiste yansıtmak yerine kendiliklerinin bir yönünü, özellikle de değersizleştirilmiş ya da grandiyöz tarafını terapiste yansıttıklarını ortaya koymuştur. Özge Hanım'ın psikoterapi seansları süresince kendiliğinin değersizleştirdiği yönünü terapiste yansıttığı düşünülmüştür:

"Sizin çalışma alanınızı bilmiyorum, ne zamandır terapi verdiğinizi ve kaç hastanız olduğunu bilmiyorum... Kafanızdaki kalıplara beni oturtmaya çalışıyorsunuz... Sürekli aynı şeyleri tekrarlıyorsunuz, bu yöntemin terapistin hastadan kurtulmak için kullandığı bir yol olduğunu okumuştum, kestirmeden bunu elde etmek istiyor olabilirsiniz."

Terapistin öfkesi, karşı-aktarımın bu güncel kavramsallaştırması çerçevesinde değerlendirilmiş, hissettiği duyguların kendi geçmişinden ve hastanın davranışlarından kaynaklanan kısımları süpervizyonda değerlendirilmiştir. Bu değerlendirme sonucunda terapist, duygularını anlamlandırabilmiş ve bu duyguları hasta ile paylaşmıştır. Özge Hanım'ın değersizleştirmeleri karşısında ona yardım etmekte zorlandığ ve öfkelendiği ifade edilmiş, sonrasında ise Özge Hanım'ın terapisti ya da terapistin yorumlarını değersizleştireceği hissedildiğinde bu Özge Hanım'ın reaksiyonundan önce onunla paylaşılmıştır. Terapistin olumsuz duygularını seans içerisinde paylaşması öncelikle olumsuz tepkiler almasına sebep olsa da terapi ilişkisinin kurulması açısından oldukça önemli faydalar sağlamıştır. Hastanın terapistin yorumlarını değersizleştirdiği anlar öncesinde neler hissettiği konuşulmuş ve bu değersizleştirmenin ihtiyaçlarını almasının önünde ne gibi engeller oluşturduğu üzerinde çalışılmıştır. Hasta seans içerisinde yorumları daha kolay alabilmeye başlamış, terapötik ittifak güçlenmiş ancak hastanın terapistin onunla yeterince ilgilenmediği ve onu yeterince önemsemediği şeklinde ortaya çıkan hasetli tutumu zaman zaman iki seans arasında kendini göstermeyi sürdürmüş ve ona iyi gelen yorumları sonraki seansa geldiğinde kabul etmediği ya da saldırgan algıladığı olmuştur. Hasetli tutumu devam etse de Özge Hanım'ın içgörüsü karşı aktarımın konuşulmasından sonra ciddi oranda artmıştır: 
"Terapilerden sonra düşünüyorum ve seans içinde sizi onayladığım şeylerin aslında öyle olmadığını fark ediyorum ve belki de her dediğimden sonra 5 dakika düşünmem gerek... Bilim olarak psikolojiyi sorguluyorum, neden terapiye geliyorum ve ne istiyorum... Empati istiyorum ancak empati alabileceğim kapıları da kapatıyorum... Söylediğiniz bazı şeyleri suçlama gibi algılıyorum, siz gerçeği söylüyorsunuz ama bende böyle bir tepki doğuyor ve savunmaya geçiyorum"

Özge Hanım ile gerçekleştirilen süreç analizleri ve karşı-aktarımın yorumlanması, 5. seanstan sonraki seansların verimliliğini artırmıştır. 5. seans ve sonraki seanslarda kendi değerliliğini hep ötekinin tutumu üzerinden değerlendirdiğini ifade etmeye başlayan, değersizlik düşüncelerinin çok çabuk aktive olabildiğini fark eden Özge Hanım ile bu duygu ve düşünceleri üzerinde çalışılmaya başlanmış ve depresif semptomlarında düşüş gözlemlenmiştir. Terapötik ittifakta ve Özge Hanım'ın depresif semptomlarında gözlemlenen bu gelişme, psikoterapi ilişkisi üzerinde hastanın olası etkilerine odaklanmakla açıklanabilir (Meares, 1992).

Yaz tatilinin araya girmesi ile Özge Hanım ile yapılan görüşmelere Özge Hanım'ın tatil dönüşüne denk gelecek şekilde bir ay ara verilmiştir. Özge Hanım tatil dönüşü randevuya gelmemiş, bir sonraki hafta seansa geldiğinde ise romantik bir ilişkisinin başladığını ve psikoterapiye daha az ihtiyaç duymaya başladığını ifade etmiştir. Bu seanstan sonra terapiye bir daha gelmemiş ve sonlandırma seansı için yapılan aramalara cevap vermemiştir. Psikoterapi sürecinde gerçekleşen bu erken bırakma, Özge Hanım gösterdiği narsisistik özelliklerle açıklanabilir. Şöyle ki, Horner ve Diamond (1996) yaptıkları çalışmada narsisistik özelliklerin dominantlığını, sınırdurum hastaların terapiyi erken bırakma oranlarıyla olumlu yönde ilişkili bulmuştur. Kernberg (1975), narsisistik hastalarda, karakteristik olarak terapiste yönelmiş talepkar ve küçük düşürücü yoğun öfke reaksiyonlarının tekrarlayan ve kronik bir şekilde gerçekleştiğini ifade etmiştir. Kernberg'e göre bu öfkenin acımasız doğası terapide gerçekleşen tüm potansiyel iyi yönleri değersizleştirir ve tedavinin devamlılı̆̆ını tehdit eder. Buna ek olarak Kernberg (1975) hastanın psikoterapiye dair yaptığı bu değersizleştirmenin erken bir dönemde ve açık bir şekilde ifade etmesinin terapinin devamlılığına yönelik ciddi bir risk faktörü oluşturduğunu ifade etmiştir. Bu doğrultuda, Özge Hanım'ın tamamlanmayan psikoterapisi, hastanın psikopatolojisi ve terapistin karşı aktarımı çerçevesinde değerlendirilebilecekken diğer bir açıklama da Özge hanımın başka bir ilişkiye açık hale gelmiş olabileceğidir.

Bir sonraki bölümde, Özge Hanım'ın psikoterapi süreci, bu süreci süpervize eden süpervizörün gözünden, terapist-hasta ilişkisi ve bu ilişsinin temelindeki dinamikler üzerinden ele alınacaktır. Bu kapsamda, hastanın narsisistik kişilik örüntüsünün süpervizyon ortamına nasıl bir etkisinin olduğu, terapistin süreçleriyle birlikte nasıl değerlendirildiği ve bunun, terapi sürecine nasıl bir geri dönüşünün olduğu aktarılacaktır.

\section{Süpervizörün Gözünden Narsisistik Kişiliklerle Terapide Terapötik İlişki}

Özge Hanım'la yürütülen terapi seansları süpervizyon ortamında değerlendirilmeye başlandığı andan itibaren, Özge Hanım'ın narsisistik bir tutumunun olduğu gruptaki terapistler ve süpervizör tarafından gözlemlenmiştir. Bu gözlem, temel olarak Özge Hanım'la yürütülen terapi seanslarının içeriği ve bu içeriğin seans sırasında terapistte ve süpervizyon sırasında diğer terapistler ve süpervizörde yarattığ dayanmaktadır.

AYNA Klinik Psikoloji Destek Ünitesi’ne başvurmasıyla, Özge Hanım'a ODTÜ Klinik Psikoloji Yüksek Lisans programı öğrencilerinden biri, terapist olarakatanmıştır. Terapist, Özge Hanım'la terapiye başladığı sırada, verdiği psikoterapi hizmeti için süpervizyon aldığı ikinci akademik dönem içerisindedir. Bu süpervizyon döneminin başında, aktif dinleme, empati kurma, içten olma, derinleştirici sorular sorma ve yorumlama gibi temel terapi becerilerini (Egan, 2010) kazanmış olduğu gözlemlenen terapist, Özge Hanım'la ilk seansına yoğun engellenmişlik ve öfke duygularının eşlik ettiğini fark etmiş 
ve bu duygularını süpervizyon grubuyla paylaşmıştır. Bu engellenmişliğin, Özge Hanım'ın seansın en başından itibaren bireysel olarak terapisti ve psikoterapi sürecini değersizleştirici yorumlarından kaynaklandığ 1 düşünülmüştür. Giustra (1985) özellikle eğitiminin başında olan terapistlerin, kendi isteğiyle terapiye başlayan bazı zorlayıcı hastaların, terapi ilişkisinin kurulmasına yönelik engelleyici tutumlarını anlamlandırmakta zorlandıklarından bahsetmiştir. Yazar, zorlayıcı hastaları, aktarımları nedeniyle terapistte yoğun karş1-aktarımlar uyandıran narsisistik - borderline kişilik örüntüsü sürekliliğinde bir yere denk gelen veya psikotik özellikler taşıyan hastalar olarak tanımlamıştır. Önceki bölümlerde aktarılanlar 1şığında, Özge Hanım'ın bütünleyici bir ego gücü geliştirmekte ve sağlıklı bir nesne ilişkisel işleyiş kurmakta sorunlar yaşadığı düşünülmüştür. Ayrıca Özge Hanım, bu sorunlarla, ihtiyaç duyduğu kabulü almasını da engelleyen bir tarzda ve inkâr, yansıtma, çarpıtma ve bölme gibi ilkel savunmalarla baş etmeye çalışmaktadır. Böylece, ona ilgi ve kabul göstermeye hazır olarak karşısına çıkan terapisti bu konuda yetersiz ve çaresiz hissettirmektedir. Terapistin, bu hislerle başa çıkmaya çalışırken kendi özgün ilişki tarzından uzaklaştığı dikkat çekmiştir. Bu durumda, terapistin Özge Hanım'la sürdürdüğü psikoterapi süreci için verilen süpervizyonun amacı, terapistin, hastanın savunmalarını anlamlandırmasını sağlamak ve hâlihazırda sahip olduğu içtenliği ve özgünlügünü seanslarda tekrar kullanabilmeye başlayarak hastasıyla derin bir ilişki kurabilmesini desteklemek olmuştur.

Narsisistik kişilik örüntüsüne sahip kişiler, kendiliklerinin aynalanmayan ya da desteklenmeyen yönlerini reddetmekte ve kendilerine sahte bir kendilik kurmaktadırlar (Halewood ve Tribe, 2003). Aynı zamanda, Kernberg (1975), narsisizmin patolojik halinin, gerçek kendilik, ideal kendilik ve ideal ötekinin içsel temsillerinin birleşmesini içerdiğini ve bu nedenle, başkalarına duyulan ihtiyaç ve hasede karşı bir savunma oluşturduğunu öne sürmektedir (akt. Halewood ve Tribe, 2003). Öte yandan, süpervizyonun, özellikle eğitiminin başındaki terapistler için narsisistik kırılmalara neden olabilen bir süreç olduğu düşünülmektedir. Bu durum, genel olarak, terapistlerin seanslar esnasında ve süpervizyonda deneyimledikleri kendiliklerinin, sahip oldukları ve ulaşmaya çabaladıkları ideal kendiliğe uymamasıyla açıklanmaktadır (Eckler-Hart, 1987; Gill, 1999). Bu uyumsuzluğun yarattığı duygular ve bu duygulara verdikleri tepkiler, terapistlerin kendi kişisel geçmiş deneyimlerinden kaynaklanmakta, ancak hastanın psikoterapi sürecini, terapisti ve terapistin yorumlarını değersizleştiren tutumlarıyla daha fazla tetiklenmektedir. Bu durumda, narsisistik kırılma yaşayan terapistlerin, hastalarının narsisistik ihtiyaçlarını karşılaması zorlaşmaktadır. Bu zorluk, bilinçli ya da bilinçdışı bir şekilde, terapist tarafından süpervizyon ortamına taşınır ve süpervizyonda paralel süreçlerin ortaya çıkması sağlanır. Süpervizyonun bu aşamadaki işlevi, terapiste kırılganlığını ve zayıflıklarını gösterebileceği bir ortam sağlamak ve seans sırasında ortaya çıkan duyguların hastanın yansıtmalarından ve kendi içselleştirmelerinden kaynaklanan kısımlarını ayrıştırabilmesine yardımcı olmaktır. Aynı zamanda, süpervizyon ilişkisi, terapistin narsisistik kırılmalarını onarıcı bir işleve de sahiptir (Gill, 2001).

Özge Hanım ve terapistinin ilişkisinin ele alındığı süpervizyon seanslarının başlarında, terapistin Özge Hanım'ın değersizleştirmelerini seans içerisinde ele alamadığı ve süpervizyona yoğun bir öfke ile geldiği gözlemlenmiştir. Bu durum, terapistin seans esnasında nasıl bir şey yapmaya ihtiyaç duyduğunun anlaşılması için sorgulandığında ise, terapist, Özge Hanım'ın çevresindekileri aşağılayan, bencil yorumlarına benzer bir içerikle karşılık verme ihtiyacı hissettiğini ifade etmiştir. Bu ihtiyacın, aynı zamanda terapistin kişisel geçmişinde eleştirel ve kabul edici olmayan figürlerle olan ilişkisinin de bir yansıması olduğu anlaşılmıştır. Terapist, bu tarz insanlarla olan ilişkisini asgari düzeyde tutmaya özen gösterdiğini, ancak terapi ilişkisinde bunun mümkün olmadığını belirtmiştir. Ayrıca, öfkesini yıkıcı bir şekilde göstererek hastayla ilişkisini bozmak ve ondan uzak durmak, kendi idealindeki terapist kimliğiyle uyuşmadığı için terapistte içsel bir çatışmaya neden olmuş ve ortaya çıkan öfkeyi, hastanın yaratmaya çalıştığı duygu olarak terapide kullanmasını engellemiştir. Aynı zamanda bu öfke, terapistin eleştirilmiş ve değersizleştirilmiş hissettiği için yaşadığı kırılma için de bir koruma işlevi görmüştür. Dolayısıyla terapist, daha fazla 
kırılmamak adına, kendi duygularını bastırmak veya inkâr etmek ve Özge Hanım'dan uzaklaşmak durumunda kalmıştır. Bu ise, Özge Hanım'ın ihtiyaç duyduğu şeyin tam tersidir; çünkü böyle bir ilişki yine ihtiyaç duyduğu aynalanmayı alamamasına neden olmuştur. Dolayısıyla, süpervizyondaki amaçlardan biri olan, terapistin özgünlüğüne kavuşabilmesi, aynı zamanda Özge Hanım'ın da ihtiyacını karşılamaya yönelik bir amaçtır. Bu amaçla, süpervizyonda öncelikle terapist ile, Özge Hanım'ın bu yaklaşımla ihtiyaç duyduğu şeyi almaktan kendini nasıl uzaklaştırdığını, kendi hissettiği duyguları karşısındakilere nasıl yansıttığını görmesi üzerine çalışılmıştır.

Terapistin kendi kişisel geçmişinin etkilerini anlayabilmek için ise, süpervizyon ortamının, terapistin kendi eksiklik ve zayıflıklarından bahsedebilecek kadar güvenli olmasına özen gösterilmiştir. Bu süreçte, terapistin ilerleme hızına saygı duyulmuş ve ortaya çıkan materyali kendisinin süpervizyon dışında da işlemlemesine izin verilmiştir. Terapistin de bu yaklaşıma uyum sağlayabildiği ve kendi duygularının seanslardaki etkisini anlayabilmek için süpervizyon seanslarına yeni bağlantılar kurmuş olarak geldiği görülmüştür. Ayrıca, terapistin seans içerisinde "hata" yapmaktan çekindiği ve Özge Hanım'la aralarındaki ilişkiyi konuşmaktan bu nedenle kaçındığ 1 fark edilmiştir. Yapmaktan en çok çekindiği hata olarak, yukarıda bahsedilen Özge Hanım'ın narsisistik tutumuna, narsisistik savunmalarla karşılık vermeyi tanımlayan terapiste, eğer "hata" yaparsa bunun süpervizyonda ele alınabileceği ve kendisinin de eksiklik ve zayıflıklarıyla kabul görebileceği hatırlatılmıştır. Bu noktada, terapistin, Özge Hanım'ın karşısında tamamen savunmasız olmadığını fark etmesi ve bu sayede, Özge Hanım tarafından yaşayabileceği narsisistik kırılmalarla seans içerisinde spontan bir şekilde kendi duygularını kullanarak baş edebilmesi ve Özge Hanım'ı aralarındaki ilişkinin gerçekliğine çekebilmesi amaçlanmıştır. Bu destekleyici, kabul edici ve aynalayıcı tutumun, terapistin narsisistik kırılmaları üzerinde onarıcı bir etkisinin olduğu ve paralelinde, terapistin Özge Hanım'a karşı empati duyabildiği, anlayış gösterebildiği ve onu destekleyebildiği dikkat çekmiştir. O noktadan sonra, seans içerisinde Özge Hanım'ın narsisistik savunmaları yerini kırılgan taraflarını daha rahat gösterebilen bir tutuma bırakmış; ancak, gerek seanslar arasında haftalık olarak verdiği aralarla, gerekse yaz tatilinden sonra terapiyi bırakmasıyla, terapide ortaya çıkan destekleyici ilişkiyi (bir diğer deyişle, önceki bölümde Özge Hanım'ın faydalanamadığından bahsedilen iyi nesneyi) içselleştirmekte zorlandığı ve bu nedenle, kırılganlığına dair farkındalığı sürdürmek istemediği düşünülmüştür.

Süpervizyonun Özge Hanım'ın terapi sürecine ve terapistin kişisel ve mesleki gelişimine yönelik amaçları gerçekleştirilirken, süpervizör özellikle kendisinde fark ettiği karşı-aktarımlardan faydalanmıştır. Özge Hanım'ın narsisistik tutumunun doğrudan hedefi olmamak, onun bu tutumu neye karşı bir savunma olarak kullandığını süpervizörün daha rahat görebilmesine ve bu savunmanın terapist üzerindeki etkisini daha rahat anlayabilmesine olanak vermiştir. $\mathrm{Bu}$ da paralel bir şekilde, terapistin öfkesinin ardındaki ihtiyaçları fark edip beraberce oraya odaklanmaya davet edebilmesini sağlamıştır. Bunun gerçekleşmesinde, süpervizyon ortamının güvenli bir ortam olması kadar, terapistin de kendi süreçlerini anlamlandırmaya hazır ve açık oluşunun da etkisi olmuştur. 


\section{Kaynaklar}

Adler, G. (1986). Psychotherapy of the narcissistic personality disorder patient: Two constrasting approach. The American Journal of Psychiatry, 143(4), 430-436.

Eckler-Hart, A. H. (1987). True and false self in the development of the psychotherapist. Psychotherapy, 24(4), 683-692.

Egan, G. (2010). The skilled helper: A problem management and opportunity development approach to helping (9th ed.). Belmont, CA: Cengage Learning.

Gabbard, G. O. (1994). Psychodynamic psychiatry in clinical practice: The DSM-IV ed. Washington, DC: American Psychiatric Press, Inc.

Gabbard, G. O. (1999). Countertransference issues in psychiatric treatment. Washington, DC: American Psychiatric Press.

Gill, S. (1999). Narcissistic vulnerability in psychoanalytic psychotherapy supervisees: Ego ideals, selfexposure and narcissistic character defenses. International Forum of Psychoanalysis, 8, 227-233.

Gill, S. (Ed.). (2001). The supervisory alliance: Facilitating the psychotherapist's learning experience. Lanham, MD: Jason Aronson.

Giustra, L. (1985). Training issues in the treatment of severely disturbed patients. American Journal of Psychotherapy, 39(1), 95-107.

Halewood, A. ve Tribe, R. (2003). What is the prevalence of narcissistic injury trainee counseling psychologists?. Psychology and Psychotherapy: Theory, Research and Practice, 76, 87-102.

Horner, M. S., \& Diamond, D. (1996). Object relations development and psychotherapy dropout in borderline outpatients. Psychoanalytic Psychology, 13(2), 205-223.

Kernberg, O. F. (1975). Borderline Conditions and Pathological Narcissism. New York: Jason Aronson.

Klein, M. (1935/2012). Manik depresif durumların psikogenezine bir katkı. (Ş. S. Postac1, Trans.). In B. Habip (Ed.), Sevgi, suçluluk ve onarım (2nd ed.). İstanbul: Kanat Kitap.

Klein, M. (1957). Envy and gratitude, a study of unconscious sources. New York: Basic Books.

Lucher, A. F., Mirsalimi, H., Moser, C.F. \& Jones, R. A. (2008). Maintaining boundaries in psychotherapy: Covert narcisistic personality characteristics and psychotherapists. Psychotherapy, 45(1), 1-14.

McWilliams, N. (1994). Psychoanalytic diagnosis: Understanding personality structure in the clinical process. New York: Guilford Press.

McWilliams, N. (2010). Psikanalitik tanı: Klinik süreç içinde kişilik yapısını anlamak (E. Kalem, Çev). İstanbul: Bilgi Üniversitesi Yayınları (1999).

Stevenson, J., \& Meares, R. (1992). An outcome study of psychotherapy for patients with borderline personality disorder. American Journal of Psychiatry, 149, 358-362.

Tura, S. M. (2005). Günümüzde Psikoterapi (2. Baskı). İstanbul: Metis Yayınları. 


\section{Summary}

This study examines the psychopathology of a patient with a narcissistic personality pattern and her defenses within the framework of object relations theory, focusing on the psychotherapy process, countertransference, and the evaluation of the supervision process. Each of four sections of this article was written by different people in the same supervision group. The first part, which was written by a peer from the supervision group, examines pathological narcissism and narcissistic defenses in a theoretical framework, and these examinations were carried out within the framework of object relations theory. The second part of this study, which is about the history of the patient, and the third part of this study, which is about psychotherapy process, were written by the patient's therapist; the symptoms of the patient are examined within the framework of object relations theory. Furthermore, the emotions of the psychotherapist that have arisen as a result of countertransference and the effects of these emotions on the psychotherapy process were analyzed. In the last section, in which supervision process was discussed from the supervisor's perspective, how the narcissistic personality pattern of the patient affected the supervision environment, how this pattern was evaluated together with personal processes of therapist and how this evaluation affected the therapy process were explained.

Keywords: Narcissistic Personality Pattern, Narcissistic Defenses, Object Relations Theory, Countertransference Reactions, Supervision 